\title{
原葋 III
}

\section{肛門周囲膿倠に゙おける治療方針 \\ 一とくに早期発見, 早期治療の重要性について一一

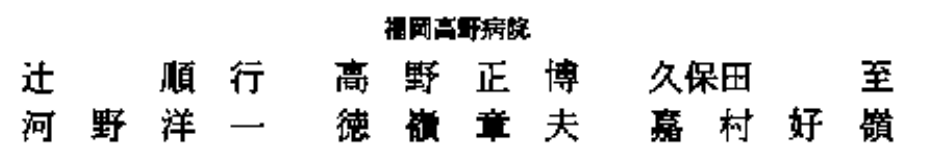

1992年 6 月より1992年 9月までに，高野病院で経肛門的超音波検査により cystic pattern

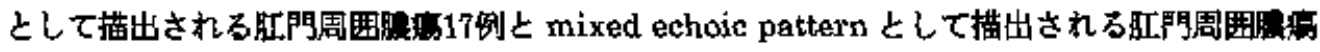

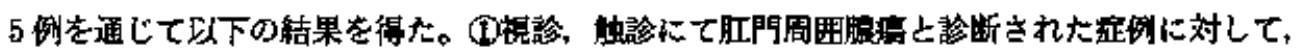
経肛門的超音波满查を施行し, cystic pattern として描出される症件と mixed echoic pat-

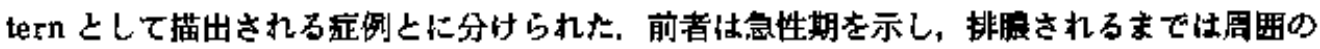

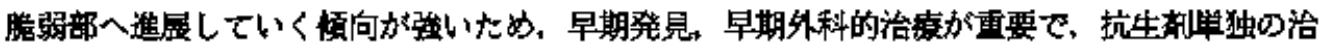

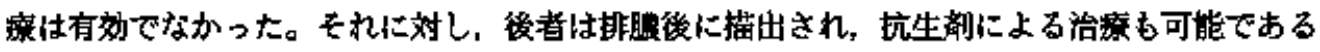

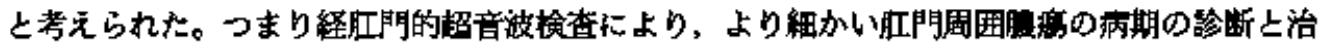
法の判定が可能でおった。

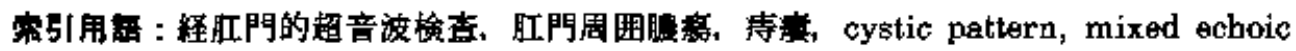
pattern

はじめに

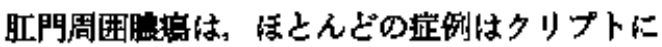

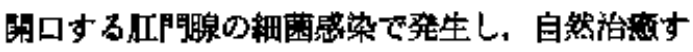
ることは稀で，周囲の組樴八搪がっていく，した がって早期に正磪な输断を下し，外科的な姏置を

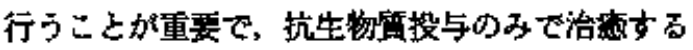
ことはないとされる。

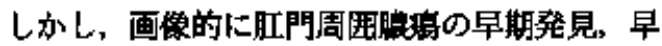
期治寞の重要性を証明した報告は今までない。今 回われわれは，早期発見，早期治密の王㩖性 を，当院を受診した症例に释肛門的超音波捈查 (transanal ultrasonography : 长下 TAUS と略す) を施行し，再維誋したので稂告する。
I. 対

1992年6月より1992年 9 月までに高野病㛡を受 診し、TAUS て cystic pattern しして描出され

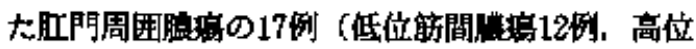

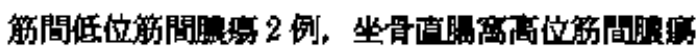
3例) と mixed echoic pattern として描出され

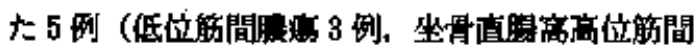

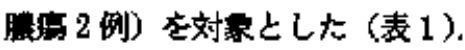

\section{II. 方法地よひ蕉政}

格查前にグリセリン浣腸100をもを行い，体位は 左側卧位とし，超音波内視銭を経肛門的に括入し た，まず男性では箱状体，女性では胵を描出し， これを12時の位置の指标とした.つぎに内視鏡を

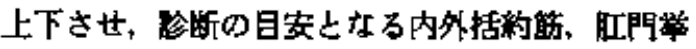


责 1 対象症湖

\begin{tabular}{|c|c|c|c|c|c|c|c|}
\hline 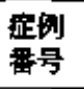 & 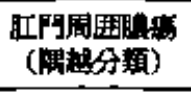 & 年必 & 性 & 切開 & 排腈前 $の$ TAUS 哄 & 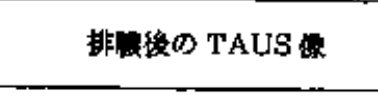 & $\begin{array}{l}\text { 抗生都 } \\
\text { D投与 }\end{array}$ \\
\hline 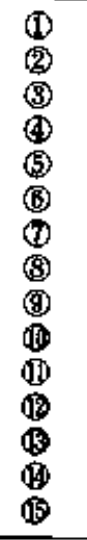 & 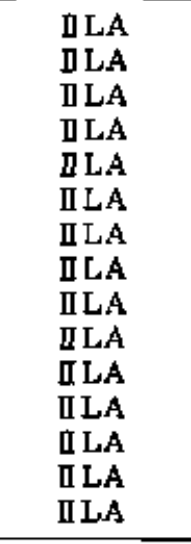 & $\begin{array}{l}18 \\
29 \\
56 \\
68 \\
43 \\
46 \\
53 \\
64 \\
73 \\
51 \\
46 \\
49 \\
43 \\
38 \\
28 \\
\end{array}$ & $\begin{array}{l}\text { 男 } \\
\text { 女 } \\
\text { 男 } \\
\text { 男 } \\
\text { 男 } \\
\text { 男 } \\
\text { 男 } \\
\text { 女 } \\
\text { 女 } \\
\text { 男 } \\
\text { 女 } \\
\text { 男 } \\
\text { 男 } \\
\text { 男 }\end{array}$ & $\begin{array}{l}\text { 有 } \\
\text { 青 } \\
\text { 有 } \\
\text { 育 } \\
\text { 育 } \\
\text { 青 } \\
\text { 有 } \\
\text { 有 } \\
\text { 有 } \\
\text { 有 } \\
\text { 有 } \\
\text { 有 } \\
\text { 有 } \\
\text { 勘 } \\
\text { 無 }\end{array}$ & $\begin{array}{l}\text { II LA (CP)* } 1 \\
\text { II LA (CP) } \\
\text { II LA (CP) } \\
\text { II LA (CP) } \\
\text { II LA (CP) } \\
\text { II LA (CP) } \\
\text { ILA (CP) } \\
\text { I LA (CP) } \\
\text { ILA (CP) } \\
\text { ILA (CP) } \\
\text { II LA (MEP) } 2 \\
\text { II LA (MEP) } \\
\text { II LA (MEP) } \\
\text { II LA (CP) } \\
\text { II LA (CP) } \\
\end{array}$ & $\begin{array}{l}\text { II LA (MEP) } \\
\text { I LA (MEP) } \\
\text { I LA (MEP) } \\
\text { II LA (MEP) } \\
\text { I LA (MEP) } \\
\text { I LA (MEP) } \\
\text { I LA (MEP) } \\
\text { II LA (MEP) } \\
\text { II LA (MEP) } \\
\text { II LA (MEP) } \\
\text { II LA (MEP) } \\
\text { II LA (MEP) } \\
\text { II LA (MEP) } \\
\text { IUA I HA I LA (CP) *3 } \\
\text { I LA (CP) } \\
\end{array}$ & $\begin{array}{l}\text { 有 } \\
\text { 有 } \\
\text { 有 } \\
\text { 㤫 } \\
\text { 㤫 } \\
\text { 有 } \\
\text { 胃 } \\
\text { 有 } \\
\text { 有 } \\
\text { 有 } \\
\text { 有 } \\
\text { 有 } \\
\text { 有 } \\
\text { 有 } \\
\text { 青 }\end{array}$ \\
\hline (1) & $\begin{array}{l}\text { II HA I LA } \\
\text { II HA II LA }\end{array}$ & $\begin{array}{l}19 \\
26 \\
\end{array}$ & $\begin{array}{l}\text { 男 } \\
\text { 男 }\end{array}$ & $\begin{array}{l}\text { 有 } \\
\text { 育 }\end{array}$ & $\begin{array}{l}\text { IHA II LA (CP) } \\
\text { II HA II LA (CP) }\end{array}$ & $\begin{array}{l}\text { II LA (MEP) } \\
\text { П LA (MEP) }\end{array}$ & 育 \\
\hline 8 & $\begin{array}{l}\text { IIUA II HA } \\
\text { IIUA I HA } \\
\text { IIUA IIHA } \\
\text { IIUA I HA } \\
\text { IIUUA II HA }\end{array}$ & $\begin{array}{l}31 \\
99 \\
43 \\
51 \\
69\end{array}$ & $\begin{array}{l}\text { 女 } \\
\text { 畭 } \\
\text { 畕 } \\
\text { 男 } \\
\text { 女女 }\end{array}$ & $\begin{array}{l}\text { 有 } \\
\text { 有 } \\
\text { 有 } \\
\text { 有 } \\
\text { 有 }\end{array}$ & $\begin{array}{l}\text { IIUA I HA (CP) } \\
\text { IIUA II HA (CP) } \\
\text { IIIUA II HA (CP) } \\
\text { IIUA I HA (MEP) } \\
\text { IIUA II HA (MEP) }\end{array}$ & $\begin{array}{l}\text { П HA (MEP) } \\
\text { II HA (MEP) } \\
\text { II HA (MEP) } \\
\text { IIUA D HA (MEP) } \\
\text { IIUA D HA (MEP) }\end{array}$ & $\begin{array}{l}\text { 育 } \\
\text { 有 } \\
\text { 有 } \\
\text { 有 } \\
\text { 有 }\end{array}$ \\
\hline
\end{tabular}

* 1 CP \& cystic pattern OU客.

* 2 MEP it mixed echoic pattern の格.

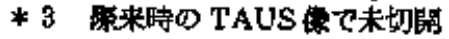

第を確認し，これら正常組䋨との成連における病

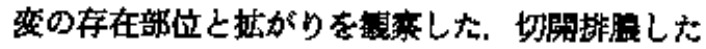

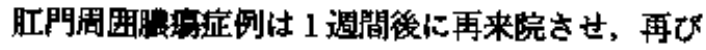

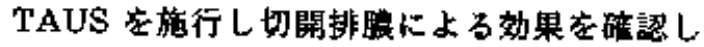

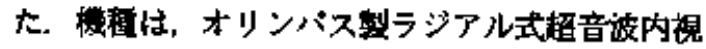

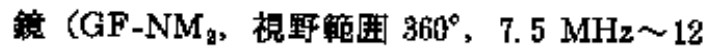

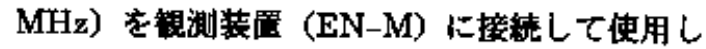
た.

\section{III. 落㮏}

1. TAUSにより cystic pattern として措出 されたILA（A：abcess の咯）の2症例は,

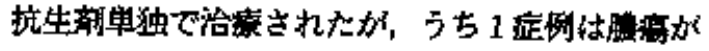
進屡し、 IIIUA ・ II HA ・ I LA となった。

症洌を提示文る.

症例 1

肚門茅を主挀上して来院した症例に TAUSを 施行し， 6 時の方向で觜状缐下の内外括約筋間に

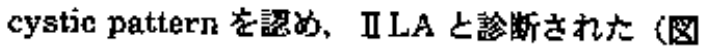
1). しかし本人の缯い希望で切開排湿は施行せ
ず，抗生剤のみを杸与し㷌宅させた。3日後に肛

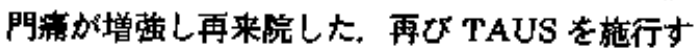
ろ上 Courtney's space 乙檑状線上下の内外括約 愬間に cystic pattern を認め，IIIUA ・ II HA • IILA と猃断された（図2，3）.

2. TAUSにより cystic pattern として描出 されたIIIUA ・IHA は，早期に切開排夙される よ 1 遇問後には mixed echoic pattern として描 出され、IIIUA は消失しIHA のみが戊存した ( $3 / 3$ 症例). Lかし. mixed echoic pattern として描出されたIIUA ・ II HA は切荓によって

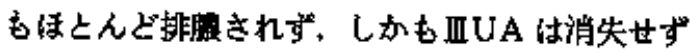
IIUA・IHAのままであった（2/2症例）。

症例它提示する。

\section{症例 2}

肛門席と熱発を主訴として来院した，TAUS を施行し, Courtney's space と菌状線上O内外 括約筋閣に cystic pattern を諗的IIUA ・ II HA

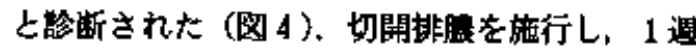
閣後に再来院させ再ひTAUS を胣行すると，雨 


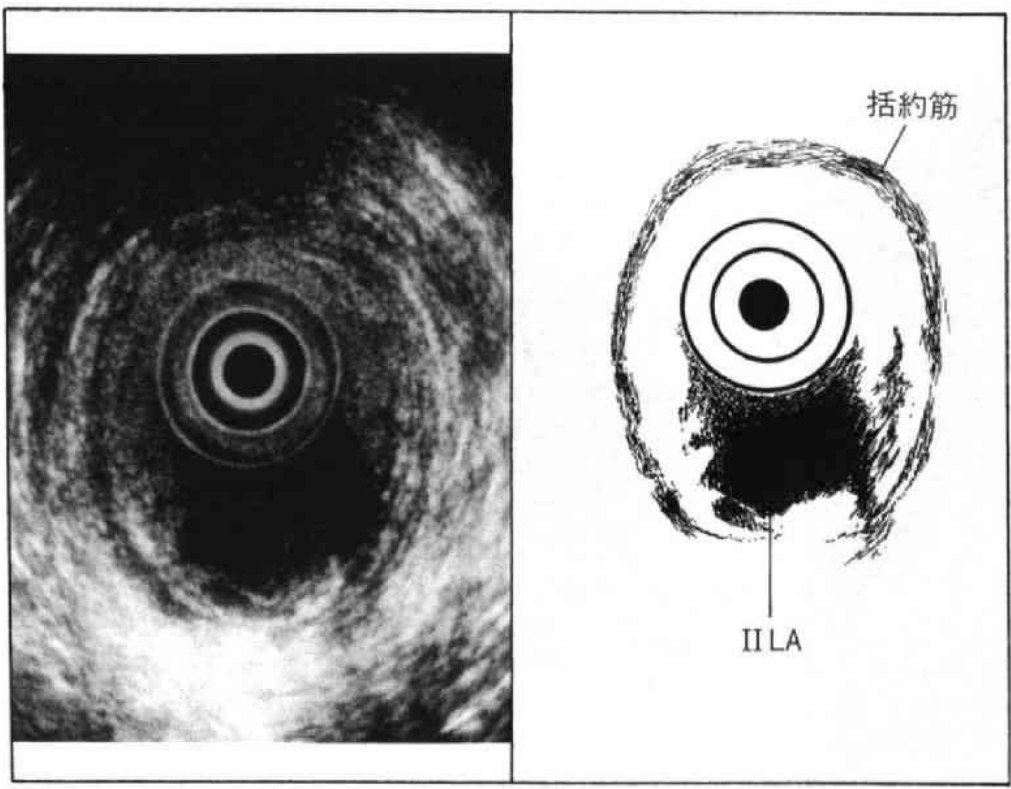

図 1 筋間に cystic pattern を認めПLA と診断される

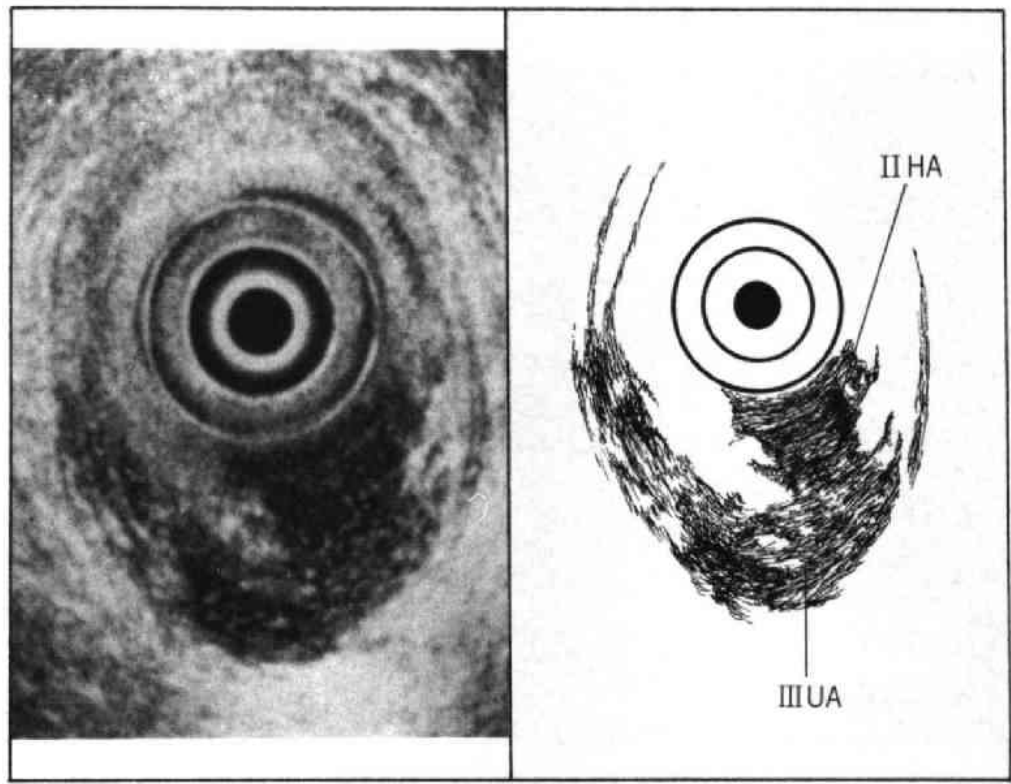

図2 坐骨直腸窝と菌状線上の筋間に cystic pattern を認め、 IIIUA II HA と䇏断される

状線上の内外括約筋間にのみ mixed echoic pattern として描出される病変を認め, II HA と診 断された（図 5 ).

症例 3

肚門部重圧感を主訴として来院した，TAUS を施行し, Courtney's space と歯状線上の内外
括約筋間に mixed echoic pattern を認め, IIIU A・IIHA と診断された (図 6). 切開を施行し たが，ほとんど排膿されず，1週間後に再来院さ せ, TAUS を施行すると, 同部位に mixed echoic pattern を認め, IIIUA ・ II HA と猃断さ れた（図7). 


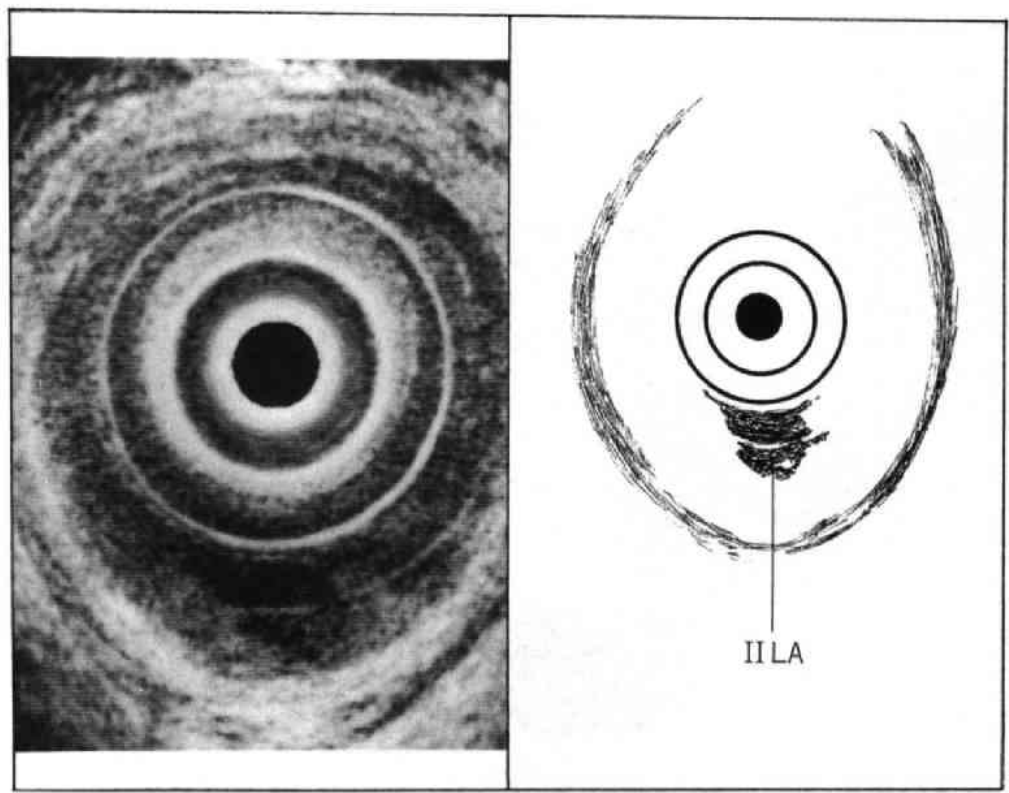

図3 㐘状線下にも cystic pattern を認めILA と彮断される

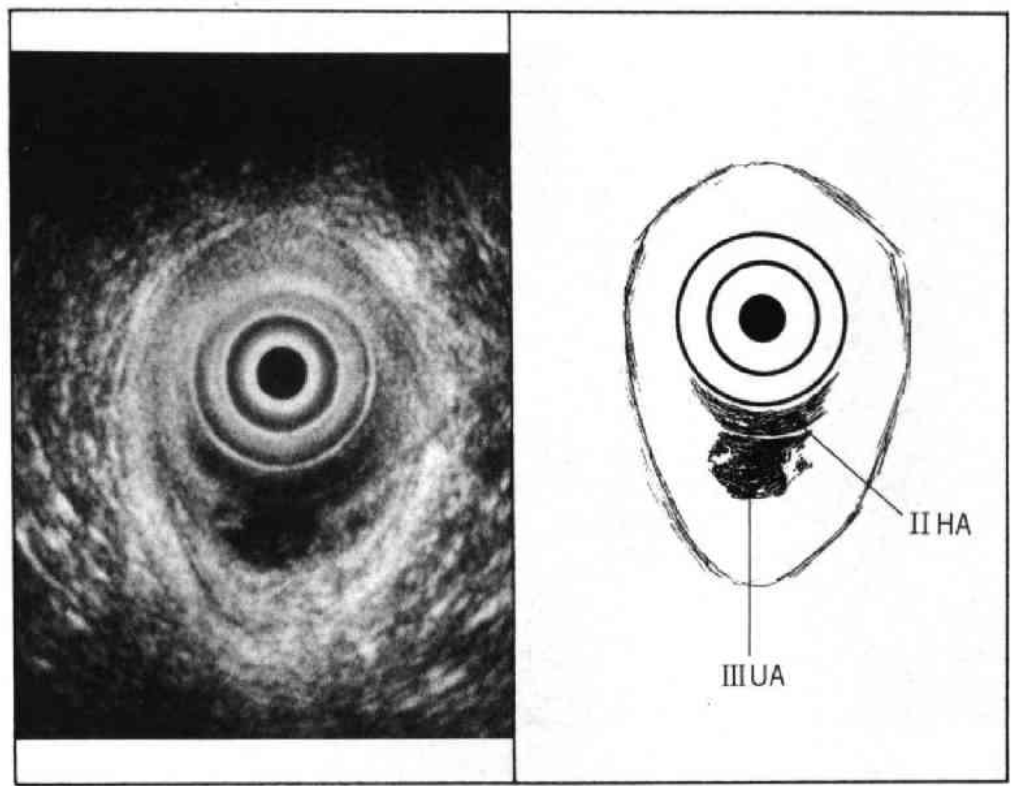

図 4 Courtney's space と歯状線上の筋間に cystic patternを認め， IIIUA II HA と診断される

3. TAUS にて cystic pattern として描出さ れたI HA ・II LA は, 早期に切開排膿すると II HA は消失し, II LA が残存した $(2 / 2$ 症例 $)$. 症例を提示する.

症例 4

肛門部痛を主訴として来院した，TAUS を施
行し, 歯状線上下の内外括約筋間に cystic pattern を認め, II HA ・ II LA と診断される（図 8 ). 切開排膿を施行し， 1 週間後に再度来院さ せ TAUS を施行すると, 歯状線下の内外括約筋 間に mixed echoic pattern として描出される病 変を認めII LA と診断された（図 9 ). 


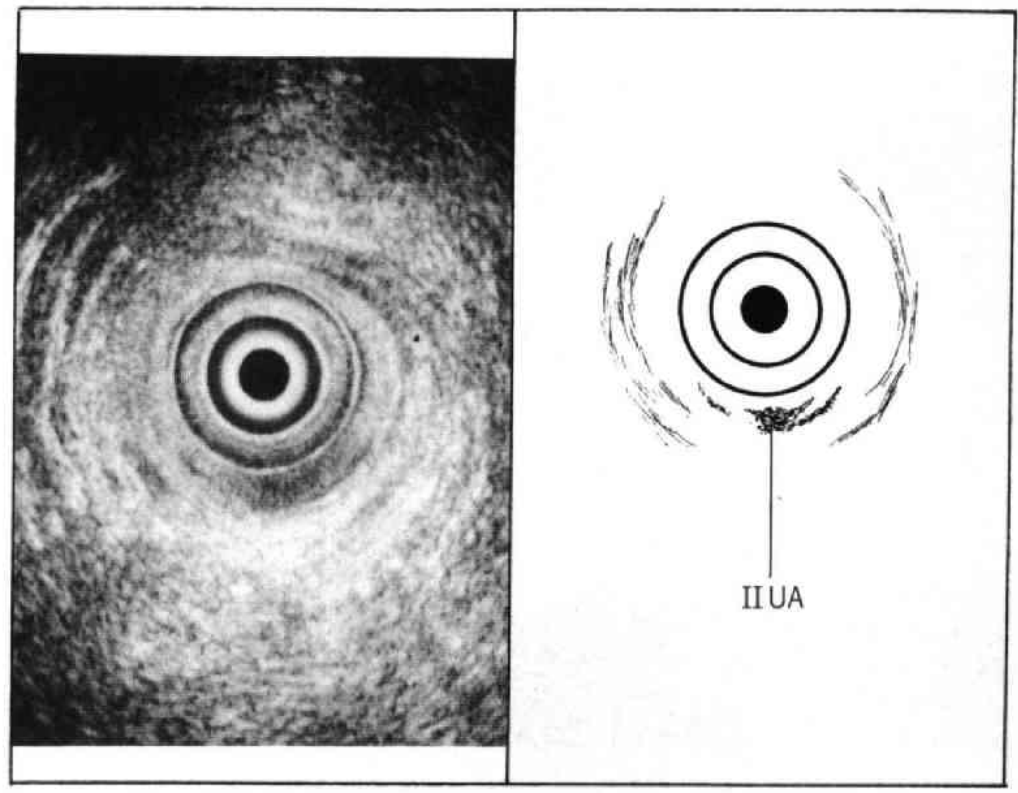

図 5 切開排膿後 1 週間後の TAUS 像で, 菌状線上の筋間に mixed echoic pattern を認め, IIUA と㟝断される

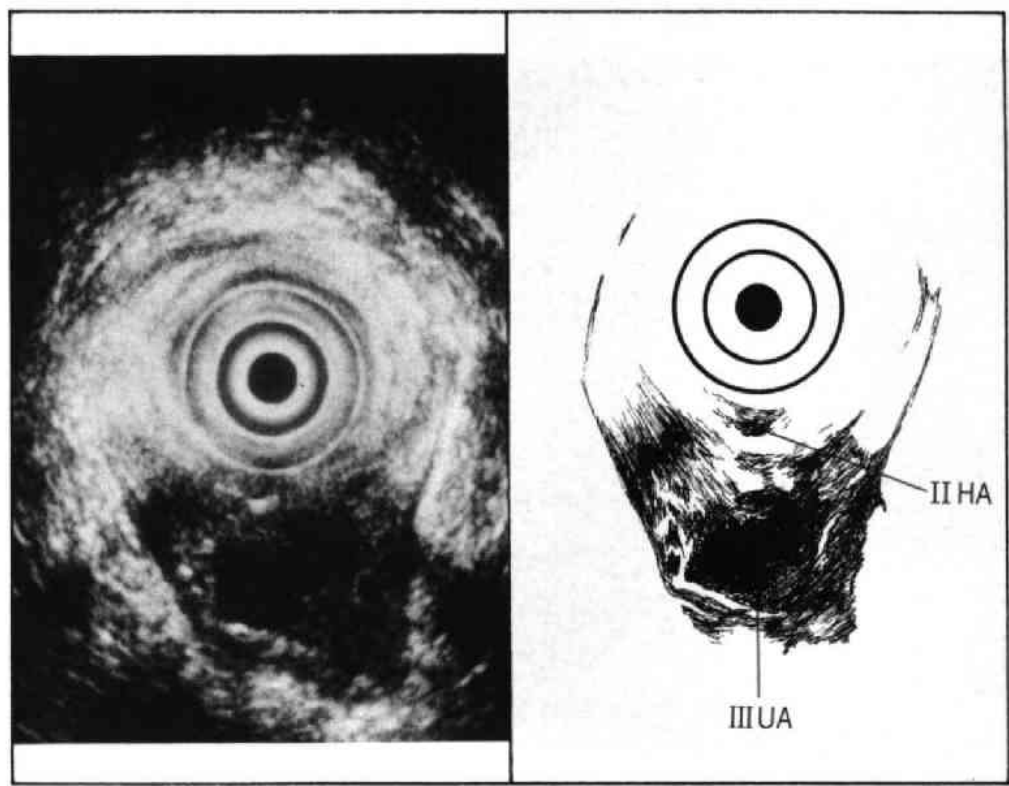

図 6 後方の坐骨直腸䆚と菌状線上の筋間に, mixed echoic pattern を認め， IIIUA IIHA と診断される

\section{IV. 考察}

肛門周囲膿瘍, 痔瘦の多くは, 歯状線に開口す る肛門腺の感染によって生ずるとされる．この説 は cryptoglandular infection theory と呼ば
れ，1880年に Herrmann \& Dessfosses 1) らに よって発表された。その後いろいろな学者が同じ 内容の発表を行ったが2-4)，1950年代にはいり， Nesselrod 5), Essenhermmer 6), Parks 7) らに より病理の面からだけでなく臨床的にもこの説が 


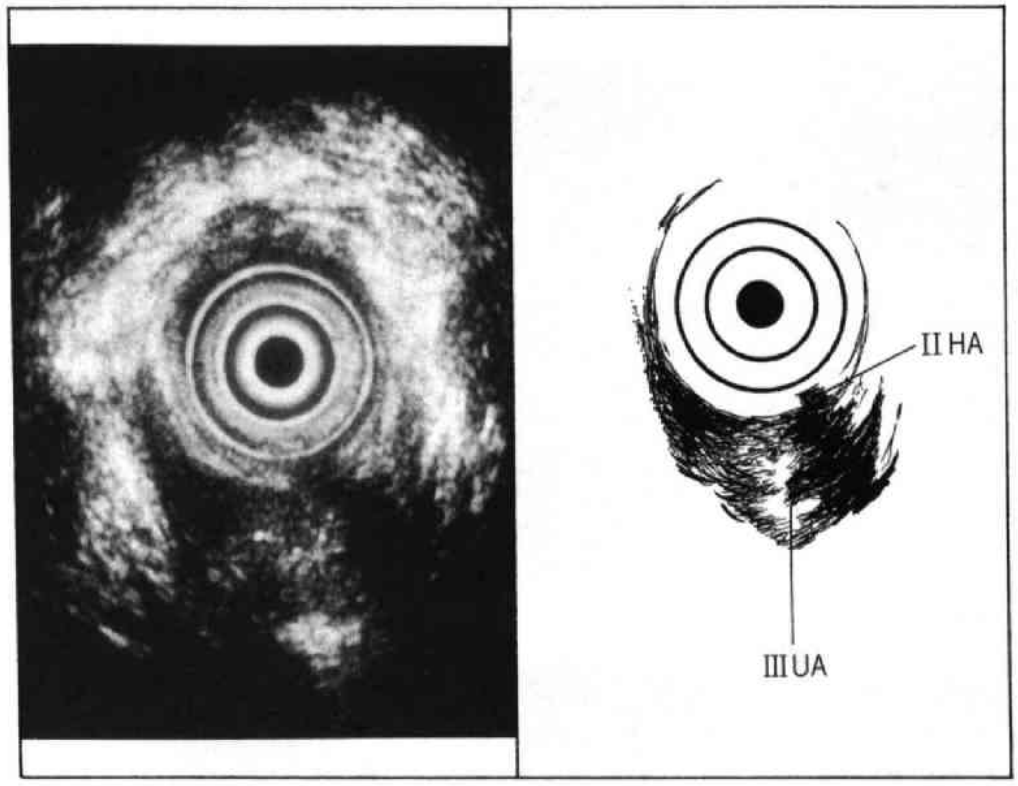

図 7 坐骨直腸窩之菌状線上の箭間に mixed echoic pattern を認め、IIIUA IIHA と診断される

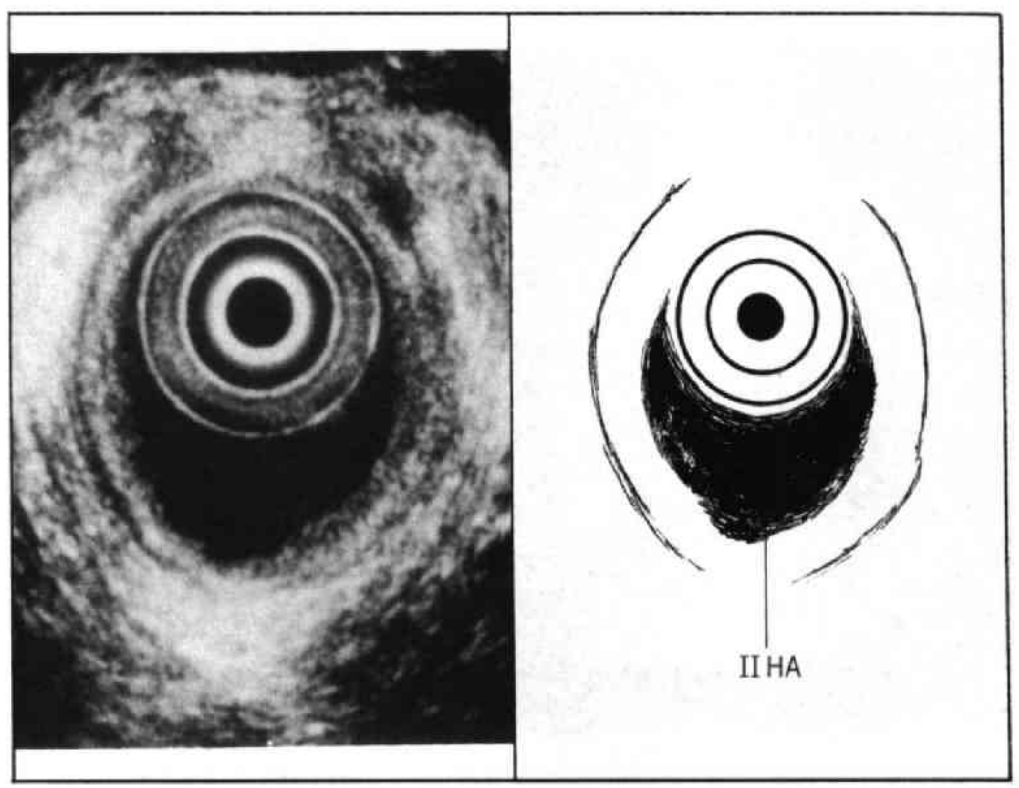

図8 茵状線上下 (下は略) の筋間に cystic pattern を

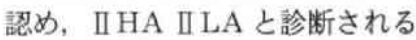

実証され，肚門周囲膿瘍・将瘦の成因として定説 化した，現在では原発口と原発巣の適切な処理に よって, 大部分の将㿉は治癒せしめることができ るようになった。術式も当初は㿉管開放術が標準 術式であったが, 最近では括約筋温存術が標準術
式となりつつある8-11). しかし肛門周囲膿瘍は, 原発口の同定が痔瘦と異なり困難なために, 一期 的に手術するか二期的に手術するかは, 諸家によ り意見が分かれている12-15). 大多数の専門家は 二期的手術, すなわちまず切開排膿を行い, 慢性 


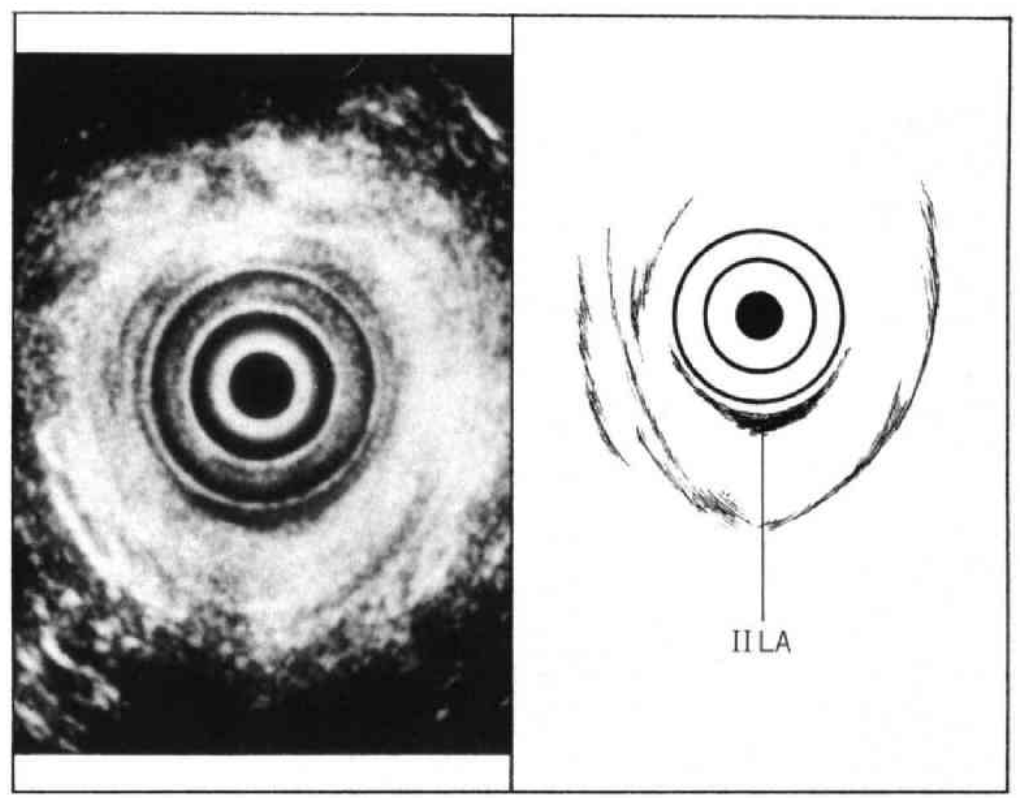

図 9 切開排膿後 1 週間後の TAUS 像で, 㐘状線下の筋間に mixed echoic pattern を珰め, II LA と郝断される

化, すなわち痔瘦となり原発口の位置が明確と なってから根治術を行う方式を支持している. 肛 門周囲膿㾤の治療の進め方について隅越は, 直腸 肛門周囲に膿㾤を形成すると，それが自然に吸収 されることは少なく, 多くは周井の脂肪組織に進 展し炎症は増強し, したがって早期に外科的切開 を加え, 炎症の進展を防がなければならならず, 肛門周囲膿瘄の治療として抗生剂単独では炎症の 増強を防ぐことはできないとしている16).

われわれの検討によれば，肛門周囲膿痖が肛門 腺の細菌感染により発症し, 肛門痛, 熱発, 肛門 の重圧感等が症状としてあらわれ, 視䧐で発赤と 腫脹を認め, 触診で圧痛と熱感を伴った硬結とし て触れる時期に TAUS を行うと, 肛門周囲膿瘍 は cystic pattern として描出され, 各型の肛門 周囲膿瘍の進展様式が, 非常に明瞭な超音波画像 として観察される17). しかし一旦自潰し，もしく は外科的治療により排膿され, 原発口から 2 次口 の間に㾇管が形成され痔瘻が出来上がる時期の触 診は比較的容易で, 瘦管を硬い索状物として触 れ, TAUS では瘦管は hypoechoic pattern と して描出される.この一連の過程を, TAUSに て観察すると膿瘍期の cystic pattern は, 排膿 により mixed echoic patternへと变化し, 瘦管
が形成された段階ではさらに hypoechoic pattern へと変化し, TAUS にて病期の判定が可能 となる。.すなわち肍門周囲膿瘍の時期は急性炎症 期に相当し，排膿されるまで周囲組織の中で抵抗 の弱い部位に拡がってゆく傾向が強い．それに対 し痔瘦は, 慢性炎症期に相当し, 炎症が再び急性 化することは稀で, 炎症がほぼ固定化した状態と 考えられる。しかしほとんどの侍瘦の症例におい て, 肞門周囲膿瘍から痔瘦に移行する間に, 痔瘦 周囲の括約筋にも炎症の影響がおよび硬化がおこ る. 将瘦の括約機能への影響を検討すると, 坐骨 直腸窩痔瘦や骨盤直腸窩痔瘦などの深部痔瘦ほ ど, 括約不全へとつながる頻度が高(18). 従って 深部痔瘦を予防することが, これらの障害を少な くすることに寄与すると考えられる. 以前われわ れは, 坐骨直腸窩膿瘍, 痔瘻はほとんどの症例に おいて高位筋間膿瘍が Courtney の space 一進 展することにより生じ, 骨盤值腸窩庤㾇症例は,

ほとんどの症例で坐骨直腸窩膿瘍が進展すること によって骨盤直腸沼痔瘻, 将瘦になると発表し た19.20).

今回の対象症例の中にも，抗生剂投与のみで治 療された低位筋間膿瘍が，3 日後に坐骨直腸窩高 位筋間低位筋間膿瘍へと進展した症例が含まれて 


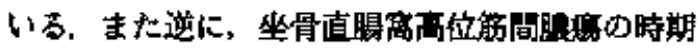

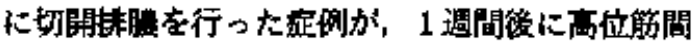

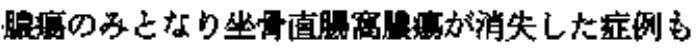

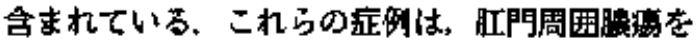
無症の早期に発見し，早急に外科的治疲加施行さ れれば，深部㨫量への移行を防ぐことがで、結 果として深部庤接穵減少させることか可能となる ことを意味している。

したがって肛門周囲腹滰の治寮の進め方は，以 下のことく行うのか娵良ではないかと考える，す なわち, TAUSにて cystic pattern こして描出

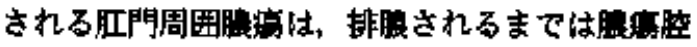
周囲の隐弱部八向かって進展していく煩向が方る ために，早期発見，旱期外科的治境が重要であ

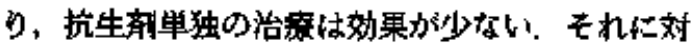
し TAUSにて mixed echoic pattern として描

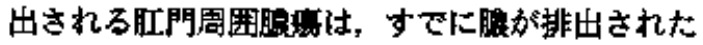
後の択態を示し，资症か谁屋する可能性が少ない たかに抗生剤による治痛も有好である。亦た早期 外科治䐂には，切開排臆と根治術とがあるが， TAUSにて cystic pattern として描出される症

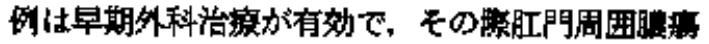
の型別で使い分けなければならないすすなわち、

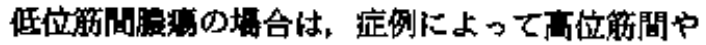

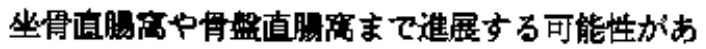

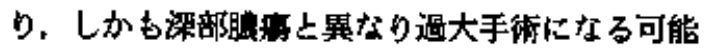
性がうない，したがって早期外科治娅は，切開排 腈か一期的根治術のどちらの手術を運択しててよ

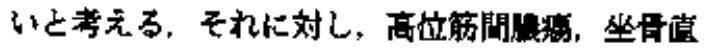

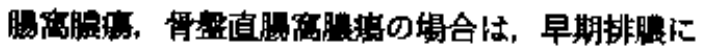

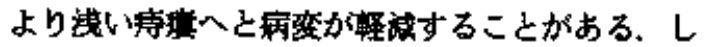

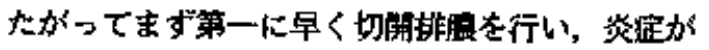

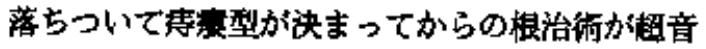

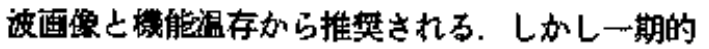
手衡の有用性も報告されており15)，その整は過大

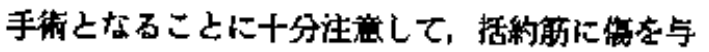
えず量小の物て治度する盛式を行うへきであると 考元万。

\section{文部}

1) Herrmann G, Dessfosses L : Sur lamnquence de la ragion doacala dn retumm.
CRA Cad Su 00 : 1301, 1880

2) Tucher CC : Anal ducts. Surg Gynecol Obstet $58: 145,1934$

3) Hill MR, Shryosk EN, Rehell FG, et al : Role of the anal glands in the patho genesis of anorectal disease. JAMA 121 : 742,1948

4) Kratger GL, Dockerty MB : Histopathology of the anal ducts. Surg Gynecol Obstet $84: 333.1047$

5) Nesselrod JP : Pathogenesis of common anorectal infection. Am J Surg $88: 815$, 1954

6) Eisanhammer $S$ : The internal anal sphineter and the anorectal abscess. Surg Gynecol Obstet $109 \div 501,1956$

7) Parks AG : Pethogenesis and treatment of fistula-in-ano. Br Med J 1:469, 1961

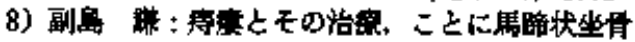

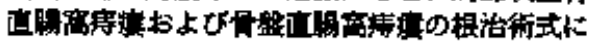

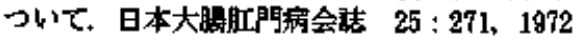

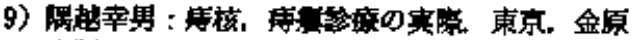
出版, 73， 1972

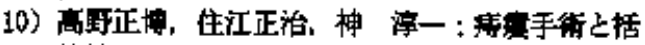

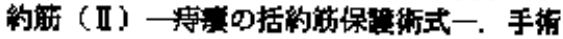
$80 \div 417,1976$

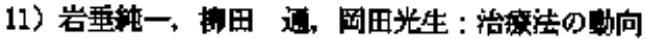

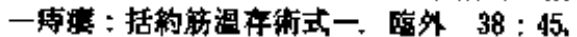
1983

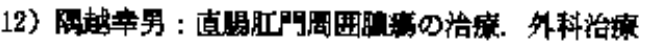
$49: 451,1988$

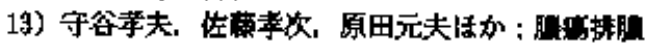

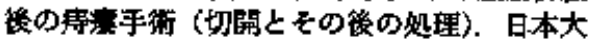
脇仜門病会声 36 ：337，1987

14) Lackhert-Murrmery ME : Anorectal problems : Treatment of abscess. Dis Colon Rectum 18:650, 1975

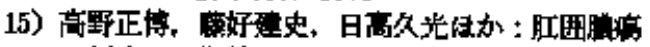
上対する一期的括約涉能温存根治街. 日本大腾 红門病会告 $40: 777,1987$

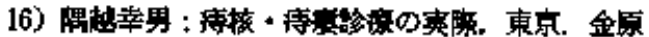
出䛲. 44, 1972

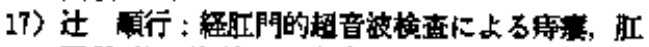

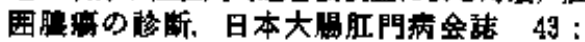
526,1980

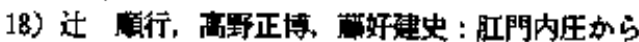

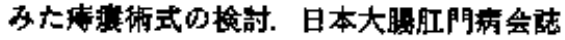
$46: 245,1998$

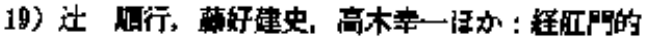

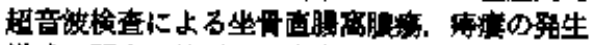

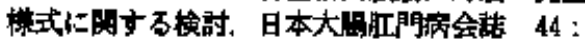
146, 1991

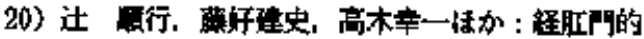

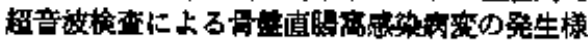

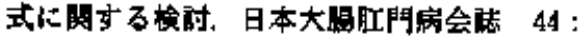
957, 1991 


\title{
Therapeutic Policy for Perianal Abscess
}

\author{
Y. Tsuji, M. Takano, I. Kubota,Y. Kono, F. Tokumine and Y. Kamura \\ Fukuoka Takano Hospital, Fukuoka
}

Twenty-two patients with perianal abscesses were examined by ultrasonography before and after surgical drainage. The following results were obtained.

1. When treated with antibiotics alone, perianal abscesses sometimes penetrated into deeper tissues. This risls must be kept in mind when treating such abscesses.

2. When a patient who was diagnosed by transanal ultrasonography as having IIIUA II HA was re-examined one week after surgical drainage, only II HA was found to have remained.

3. When a patient who was diagnosed by transanal ultrasonography as having II HA II LA was re-examined one week after surgical drainage, only II LA was found to have remained. 